\title{
'The University will be the battleground for freedom': solidarity and diaspora organising in London
}

\section{Rohit K Dasgupta}

Winchester School of Art, University of Southampton, Winchester, UK

The recent stand-off between the students of Jawaharlal Nehru University and the government of India is unlike any of the more recent campus-based protests and student agitation movements that have been taking place around the country. ${ }^{1}$ Much of the media coverage has centred around the arrest of the JNUSU President Kanhaiya Kumar on 12 February 2016 followed by the arrests of Umar Khalid and Anirban Bhattacharya. All three arrests were made on the ground of anti-national sloganeering that took place during the death anniversary of Afzal Guru, who was accused of the 2001 parliamentary attack. Guru's execution led to protests and dispute amongst activists as well as parliamentarians and there still remains much debate about the lack of judicial procedures that led to his hanging.

The crackdown on these three students followed closely on the heel of Rohith Vemula, a Dalit student who committed suicide at the University of Hyderabad on 17 January 2016. In Vemula's case, he was protesting against the caste discrimination and loss of scholarship that resulted from his protest activities. Both cases have led to reignited debate on freedom of speech and the relevance of the sedition law, a colonial remnant that was used by the British to silence nationalists and anticolonial activists. Ironically Section 124a (The Sedition Act) which was struck off by the British Government in the UK in 2009 remains in India in the same way as another colonial construct, Section 377 (another colonial remnant), which criminalises homosexuality.

Both cases have been widely condemned by academics and open letters have been written to show support and solidarity. ${ }^{2}$ I helped organise the two demonstrations in the UK to show our solidarity for the JNU students and more largely to support the freedom to dissent. The first demonstration was organised on the 17 February 2016 outside the School of Oriental and African Studies, University of London, where faculty and students read out portions from Kanhaiya Kumar's supposedly seditious speech. ${ }^{3}$ The former Indian attorney General Soli Sorabjee who was present at JNU where these allegedly seditious slogans were raised has categorically stated that the content of Kumar's speech does not amount to sedition. ${ }^{4}$ In doing so, we were also joining colleagues from around the world who used this act of reading a 'seditious' speech to challenge the government's decision to arrest Kumar. What was also unique about the way in which the speech was read was making it our own and using it to also bring attention to our own individual/local situations - a recension rather than repetition.

\section{Image 1: reading Kanhaiya's 'seditious' speech outside SOAS, 17 February 2016}

The second demonstration was held outside the Indian High Commission in London on the 24th of February, 2016, and was a larger effort by bringing across academics and activists from a range of institutions across the country (representation was found through SOAS, LSE, Southampton, Kings College, Royal Holloway and Warwick, amongst others). Whilst conceived as a student- and facultyled protest, it quickly outgrew that. Phones started coming in from several organisations and civil liberty groups who all wanted to attend and show solidarity. The Indian Workers Association was represented by their Bexley branch followed by the South Asia Solidarity Group, the Jammu and 
Kashmir Awami Party and volunteers from the Awaaz Network. The Hindustan Times carried a lengthy report about the demonstration terming it the first major demonstration abroad outside a government establishment. ${ }^{5}$ I along with Priyanka Basu my co-organiser realised that our demonstration had become a rallying point for several groups who all felt marginalised and discriminated by the present government. Thus, the protest could no longer just be a symbolic gathering but rather we were able to use this platform to bring together people with different views and causes for whom the JNU stand-off had become a catalyst to question lack of freedom. The slogans raised that day also symbolised this large umbrella under which we gathered.

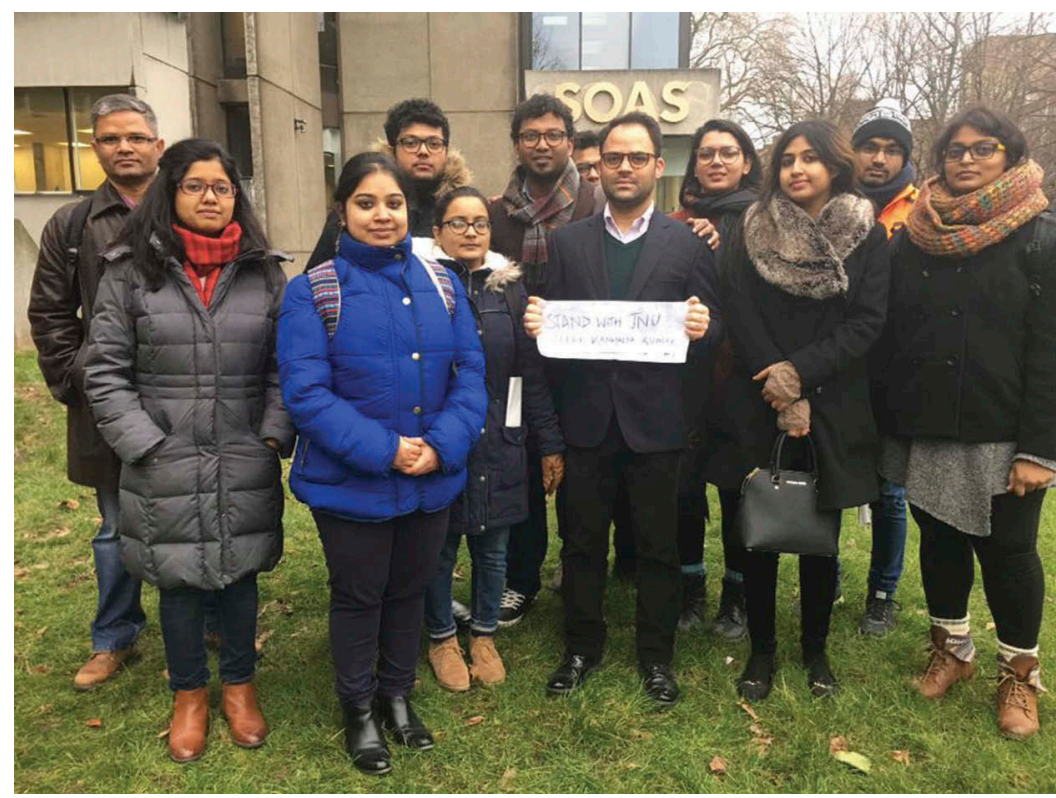

Courtesy of Debanjali Biswas.

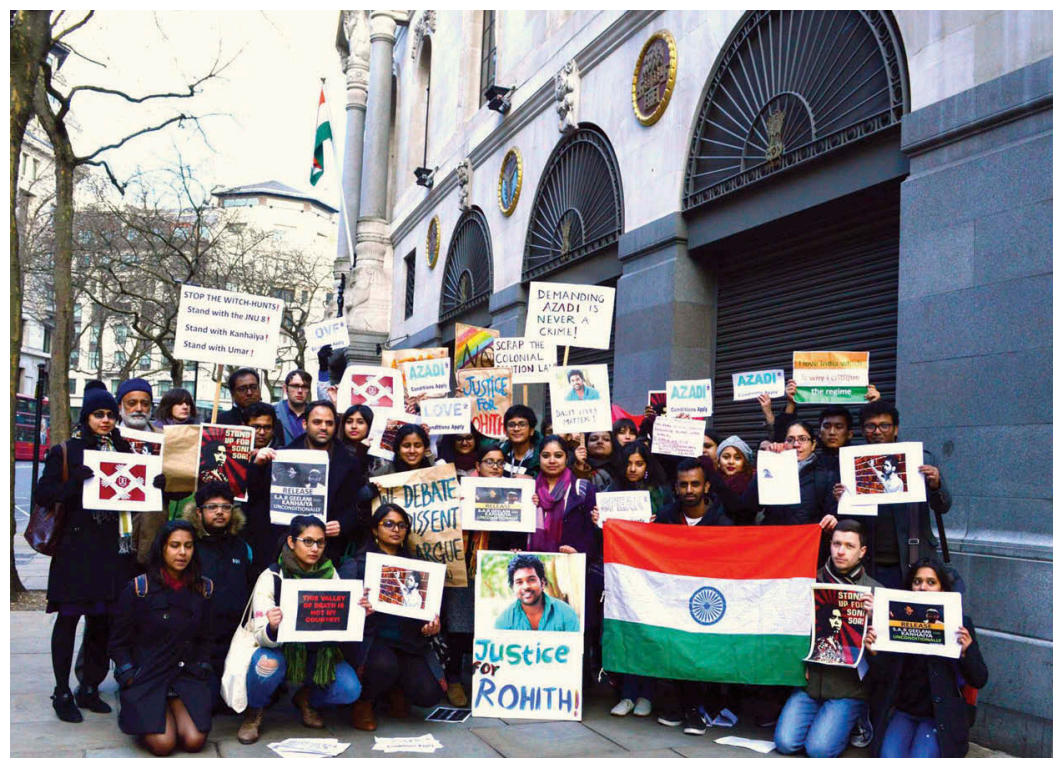




\section{Image 2: protesting outside the Indian High Commission, 24 February 2016}

Azaadi (freedom) became a rallying cry. Several posters called for Azaadi - freedom from caste oppression, freedom for Kashmiri brothers and sisters, freedom for queer people undergoing tremendous levels of violence since the 2013 judgement and freedom for Adivasi activists in Bastar who have been tortured in recent days.

\section{Image 3: 'Azaadi: Conditions Apply'}

De Certeau, in the context of the student uprising in Paris in 1968, called it a symbolic revolution and asked 'Where is the fiction? Where is the real? ${ }^{6}$ JNU and the student unrest across India from Vemula to Umar have transformed into a symbolic protest to safeguard and protect a progressive India. As we discussed in the demonstrations, JNU for all of us stands as a symbolic beacon of progressive politics. What Kanhaiya Kumar and Umar Khalid were fighting for was not a single issue but for a radical transformation of the political system, a watershed moment.

As a media scholar what fascinates me the most is the way in which the media played this out as a case of protecting India from the 'enemy within'. Most notably, Zee News and Times Now called for mob justice and were eager to paint the students as privileged, spoilt and anti-nationals and pitted them against army personnel and national martyrs. Billig in his famous thesis on nationalism calls this banal nationalism - a series of symbols (the martyr, the flag, the precarious borders), which is used subliminally to remind us of the centrality the nation is to our lives and how servicing the nation becomes the prime objective of the citizenry. ${ }^{7}$ The Home Minister, Rajnath Singh, repeated the same line announcing that anyone who questioned India's policies 'would not be tolerated or spared.' Several protesters who attended the demonstration in London were also vocal about the role of the Indian media and were generally suspicious of the media (NDTV, Aaj Tak, The Hindu and Associated Press were present) who were present there to interview us. ${ }^{8}$ Some were also afraid that if they identified themselves, their families back in India would be targeted and harassed. This was one of the most troubling features of the demonstration as we wanted our protest to be publicised and tell the protesters in India that we stood with them but at the same time were also aware of the dangers that came with it.

The JNU stand-off is by no means an isolated case. There have been disruptions of the screenings of Muzaffarnagar Baqi Hain, a film on communal violence in Uttar Pradesh in 2013 and it was the screening of this film that ultimately led to Vemula's suspension. The Indian university campus for many of us holds a symbolic nostalgia, it is where some of us cut our political teeth. It is a space
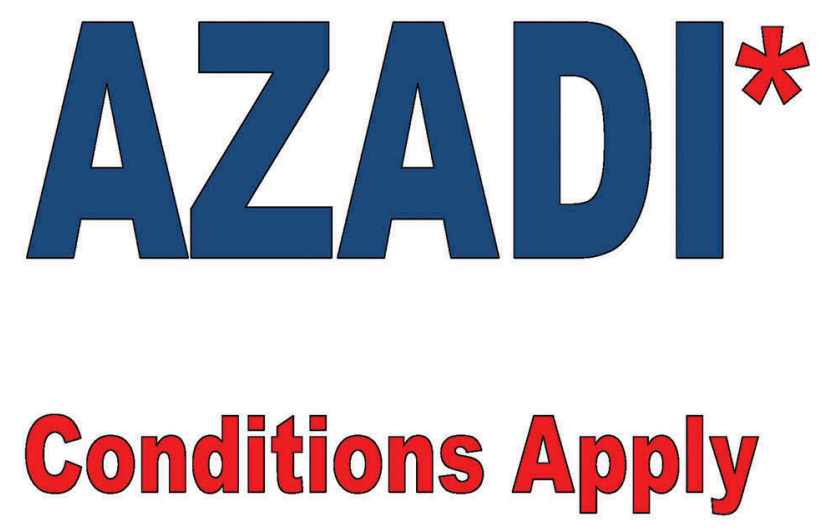

Courtesy of Jonathan Daniel Luther. 
where many of us learnt critical solidarity. To see an assault on that very space that promises and encourages us to explore power relations, status quos and privilege is very personal.

The relations between members of the public and those holding political office in India is in a period of transformative flux. There are new expectations, and meanings of citizenship are being contested and debated. People are no longer content at just being heard on the polling day. Topdown ways of engaging with the public using established bureaucratic routines have failed and in most cases simply inadequate. Interactive digital media and the growth of digital technologies are changing and improving communication.

For many of us South Asians in the United Kingdom, it was part of questioning a global and systematic pressure on university budgets, tightening Higher Education funding and most importantly taking away the ladder of opportunity that education brings with it. The student unrest that began with the Occupy UGC movement to stop the government from discontinuing the non-NET research fellowship, to Vemula's activism against caste discrimination in Higher Education to the JNU students' demand to be able to question the state, are all symptomatic of the rejuvenation of campus politics around the country.

Postscript: Kanhaiya Kumar was given bail on 3 March 2016. Interestingly appended to his bail was a lengthy sermon where the judge warns that freedom of speech needs to be checked and whilst Kumar himself was not responsible for the 'anti-Indian' slogans as President of JNUSU he must use his influence to keep a check on this, and perhaps most insidiously, the court has claimed that 'not all statements can be protected under freedom of expression'.?

\section{Notes}

1. For example, the \#HokKolorob movement in Jadavpur University in 2014; the stand-off between the administration and students at Burdwan University, 2016.

2. The Open Letter to the University of Hyderabad VC can be accessed here: http://www.thehindu.com/news/ national/dalit-student-rohith-vemula-suicide-an-open-letter-to-vicechancellor-of-university-of-hyderabad/arti cle8124405.ece. The Solidarity Statement for the JNU Students is available here: http://kafila.org/2016/02/19/ standwithjnu-solidarity-statement-by-academics-in-the-uk/ (Accessed on 04 March, 2016).

3. This video can be accessed here: https://www.youtube.com/watch?v=UW1O-BF76Lo (Accessed on 04 March, 2016).

4. See Sorabjee's interview here: http://indiatoday.intoday.in/story/anti-national-slogans-are-not-sedition-saysformer-attorney-general-sorabjee/1/596950.html (Accessed on 04 March, 2016).

5. Available here: tinyurl.com/j7plwnm (Accessed on 04 March, 2016).

6. de Certeau, The Capture of Speech.

7. Billig, Banal Nationalism.

8. Some of the video coverage can be seen here: http://www.thequint.com/videos/2016/02/25/jnu-row-respect-theright-of-dissent-say-protestors-in-uk (Accessed on 04 March, 2016).

9. The bail order is available here: http://s3.documentcloud.org/documents/2730519/Kanhaiya-Kumar-bail.pdf (Accessed on 04 March, 2016). Interestingly, the judge begins it with the popular patriotic Hindi film song 'Mere desh ki dharti'.

\section{Disclosure statement}

No potential conflict of interest was reported by the author.

\section{Bibliography}

Billig, M. Banal Nationalism. London: Sage, 1995.

de Certeau, M. The Capture of Speech and Other Political Writings. Minnesota: Universty of Minnesota Press, 1997. 